\title{
How to compare energy performance requirements of Japanese and European office buildings
}

\author{
Kaiser Ahmed ${ }^{1, *}$, Gyuyoung Yoon ${ }^{2}$, Makiko Ukai ${ }^{3}$, and Jarek Kurnitski 1,4 \\ ${ }^{1}$ Department of Civil Engineering, Aalto University, Finland \\ ${ }^{2}$ Graduate school of Design and Architecture, Nagoya City University, Japan \\ ${ }^{3}$ Graduate School of Environmental Studies, Nagoya University, Japan \\ ${ }^{4}$ Department of Civil Engineering and Architecture, Tallinn University of Technology, Estonia
}

\begin{abstract}
This study applied the normalisation method that enabled to compare the energy performance of buildings from European and Japanese climates. A reference office building was simulated with national input data and weather file in order to estimate the thermal conductance of building model and heating degree-days for a reference climate. Based on simulated results, economic insulation thickness and thermal transmittance of windows for all climates were determined. A reference office building corresponding to Japanese ZEB Ready performance was moved with this method to Estonian and French climates. The results compared to national NZEB requirements and EC NZEB Nordic and Oceanic recommendations. It was found that the Japanese ZEB Ready building configuration with air source heat pump was very close to EC NZEB recommendations. However, in the case of district heating and gas-boiler heat sources, it was needed to improve Japanese ZEB Ready building configuration in order to meet EC NZEB recommendations. Estonian NZEB requirement met EC recommendation with both heat sources, but French NZEB requirement was much less ambitious.
\end{abstract}

Keywords: Energy performance, Primary energy, Climate correction, NZEB, ZEB Ready

\section{Introduction}

The comparison of energy performance requirement in buildings from different locations is difficult due to the variances of building parameters, national input values, regulation of indoor thermal comfort. Also, keeping the same input parameters do not ensure a similar amount of energy saving in buildings due to the effect of climatic parameters. Heating and cooling needs in buildings are mainly influenced by the climatic parameters such as dry and wet bulb temperature, and solar radiation $[1,2]$. Degree-day method based on air temperature has been used in order to find out the energy use in buildings [1]. However, a constant base temperature could not account the dynamic behaviours of weather effects that might lead to considerable errors [3]. Therefore, dynamic energy simulation models could be used for estimating the energy use in buildings, which accounted for the dynamics of weather parameters $[4,5]$.

Aiming to transfigure the heating and cooling needs in buildings from one climate region to another are also surrounded by many uncertainties. Solar air temperature based heating degree-days (HDD) was used in order to determine the heating and cooling needs when a building moved from France to Estonia [6]. The accuracy of normalisation and the correction factors was increased by accounting the solar heat in addition to the dry bulb temperature [6]. The main drawback of this method was that it kept the same insulation level in both climates, which is usually not the case [6]. Therefore, the concept of an economic insulation thickness was brought up together, which ensured that the buildings were optimally insulated in both climates. An Estonian cost optimal office building was considered, which had optimal insulation thickness of façade, optimal heat transmittance of the windows, etc. and presented the optimal cost solution [6]. An economic insulation thickness, obtained from the HDD based on solar air temperature, was applied in order to estimate the heating and cooling needs in buildings from one climate region to another [6].

The European Energy Performance of Buildings Directive (EPBD) set an ambitious target of achieving the energy performance of nearly zero energy building (NZEB). European Commission (EC) officially recommended that the new buildings should have the best technology that available and well introduced in the market that follows the political and legal consideration [7]. EC also set a numerical benchmark for NZEB, as shown in Table 1 [7]. Buildings in Member states (MS) shall have very high-energy performance, and MS can outline the definition of high-energy performance as well as their unique method for energy calculation. This has brought up the question of how much the variations of energy use can be caused due to the variation of input data and method for energy calculation. The methodology of energy calculation for an apartment building alongside with different input data sets from Estonia, Finland, Sweden and Norway were considered in order to show the strictest NZEB level in the MS [8]. In a similar context, a simulation-based study was performed that compared the energy performance of a detached house, apartment building, office building from Finland, Denmark, Sweden and Norway [9]. The input values followed the Finnish, Danish, Swedish and Norwegian NZEB regulations and used a common energy calculation method. The results found that the Danish NZEB requirement for office buildings was the most stringent one, followed by Sweden, Norway, Estonia, and Finland [9]. 
Table 1. EC recommendation for primary energy use in office buildings [7].

\begin{tabular}{|c|c|c|c|c|}
\hline Energy use & $\begin{array}{l}\text { Mediterranean } \\
\text { Zone 1: } \\
\text { Catania, } \\
\text { Athens, } \\
\text { Larnaca, } \\
\text { Luga, Seville, } \\
\text { Palermo }\end{array}$ & $\begin{array}{l}\text { Oceanic } \\
\text { Zone 4: Paris, } \\
\text { Amsterdam, Berlin, } \\
\text { Brussels, Copenhagen, } \\
\text { Dublin, London, } \\
\text { Prague, Warszawa }\end{array}$ & $\begin{array}{l}\text { Continental } \\
\text { Zone 3: } \\
\text { Budapest, } \\
\text { Bratislava, } \\
\text { Ljubljana, } \\
\text { Milan, Vienna }\end{array}$ & $\begin{array}{l}\text { Nordic } \\
\text { Zone 5: } \\
\text { Stockholm, } \\
\text { Tallinn, } \\
\text { Helsinki, Riga, } \\
\text { Stockholm, } \\
\text { Gdansk, } \\
\text { Tovarene }\end{array}$ \\
\hline $\begin{array}{l}\text { Net primary energy } \\
\mathrm{kWh} /\left(\mathrm{m}^{2} \mathrm{a}\right)\end{array}$ & $20-30$ & $40-55$ & $40-55$ & $55-70$ \\
\hline $\begin{array}{l}\text { Primary energy w/o } \\
\left.\text { RES kWh/(m }{ }^{2} \mathrm{a}\right)\end{array}$ & $80-90$ & $85-100$ & $85-100$ & $85-100$ \\
\hline $\begin{array}{l}\text { on-site RES } \\
\text { sources } \mathrm{kWh} /\left(\mathrm{m}^{2} \mathrm{a}\right)\end{array}$ & 60 & 45 & 45 & 30 \\
\hline
\end{tabular}

The objective of this study was to apply the normalisation method with the minimum amount of building specific parameters in order to compare the energy performance of buildings from European and Japanese (Sapporo) climates. New normalisation method based on building thermal conductance was introduced. Also, an economic insulation concept was applied that allowed to adjust the insulation thickness according to the European climate. A reference cost optimal office building with Japanese input values and technical solutions were simulated in order to achieve a similar primary energy use corresponding to the present Japanese requirement. The technical solution and input values were improved to reduce the primary energy use by $50 \%$ that corresponds to Japanese ZEB Ready definition. This building model was moved from Japanese to European climate with the consideration of an economical thickness concept and performed simulations with national and EC input data. Additional adjustment of building parameters and technical solution were done if needed, for the compliance of national and EC's NZEB benchmarks. Afterwards, the model moved from European to Japanese (Sapporo) climate while accounting the concept of an economical thickness and performed simulations with Japanese input data. The obtained primary energy showed the most stringent national NZEB requirement and allowed comparison between European NZEB and Japanese ZEB Ready performance levels.

\section{Method}

A building simulation method was used to compare the energy performance of an office building from two climate regions. Thermal conductance $\left(G_{\text {ref }}\right)$ of the model and simulated energy need for heating $\left(E_{h^{r e f}}\right)$ of the reference climate were used to calculate corresponding heating degree-days $\left(H_{D D}\right)$ by equation (3). This enabled to conduct optimal insulation thickness adjustment from one climate to another, equation (4). The detailed description of method was discussed in [6].

$$
E_{j, \text { Norm }}=E_{j} \cdot \frac{D D_{\text {ref }}}{D D_{j}}
$$

$$
\begin{gathered}
D D_{j}=\frac{E_{j}}{G_{j}} * \frac{1000}{24} \\
\frac{H_{D D^{j}}}{H_{D D^{r e f}}}=\frac{E_{h^{j}}}{E_{h^{r e f}}} * \frac{G_{r e f}}{G_{j}} \\
U_{o p t}^{r e f}=U_{o p t}^{j} \sqrt{\frac{H_{D D^{j}}}{H_{D D^{r e f}}}}
\end{gathered}
$$

where, $E_{j, N o r m}$, normalized energy (heat load for heating or cooling) need in the reference climate $\left(\frac{k W h}{m^{2} a}\right)$, $E_{j}$, energy (space heating or cooling) need in the actual climate $\left(\frac{k W h}{m^{2} a}\right), D D_{r e f}$, heating or cooling degree days in reference climate $\left({ }^{\circ} \mathrm{Cd}\right), D D_{j}$, heating or cooling degree days in the actual climate $\left({ }^{\circ} \mathrm{Cd}\right), G_{j}$, thermal conductance of respective building $\left(\frac{W}{K}\right), G_{r e f}$, thermal conductance of reference building $\left(\frac{W}{K}\right), E_{h^{j}}$, energy need for space heating in the actual climate $\left(\frac{k W h}{m^{2} a}\right), E_{h^{r e f}}$, energy need for space heating in the reference climate $\left(\frac{k W h}{m^{2} a}\right), U_{o p t}^{r e f}$, optimal thermal transmittance of reference building $\left(\frac{W}{m^{2} K}\right), U_{o p t}^{j}$, optimal thermal transmittance of respective building $\left(\frac{W}{m^{2} K}\right), H_{D D^{r e f}}$, heating degree days of a reference (Estonian) office building $\left({ }^{\circ} \mathrm{Cd}\right), H_{D D^{j}}$, heating degree days for respective building $\left({ }^{\circ} \mathrm{Cd}\right)$.

In the building simulation method, economic insulation thickness concept was applied where insulation level of building envelope and window ' $U$ value' was adjusted according to the climate (Equation (4)) [6]. Standard EC and national input data with corresponding weather file (test reference year) were used in simulation tools in order to compare the energy performance of buildings from two climate regions. The estimated ' $U$ value' according to the equation (4) are shown in Table 4 and Table 5.

Every European member state has defined NZEB energy performance requirements, energy flows and primary energy factors for energy calculation. This data for an office building, according to the national regulation are shown in Table 2. 
Table 2. National requirements, energy flows, and primary energy factors according to the national regulation.

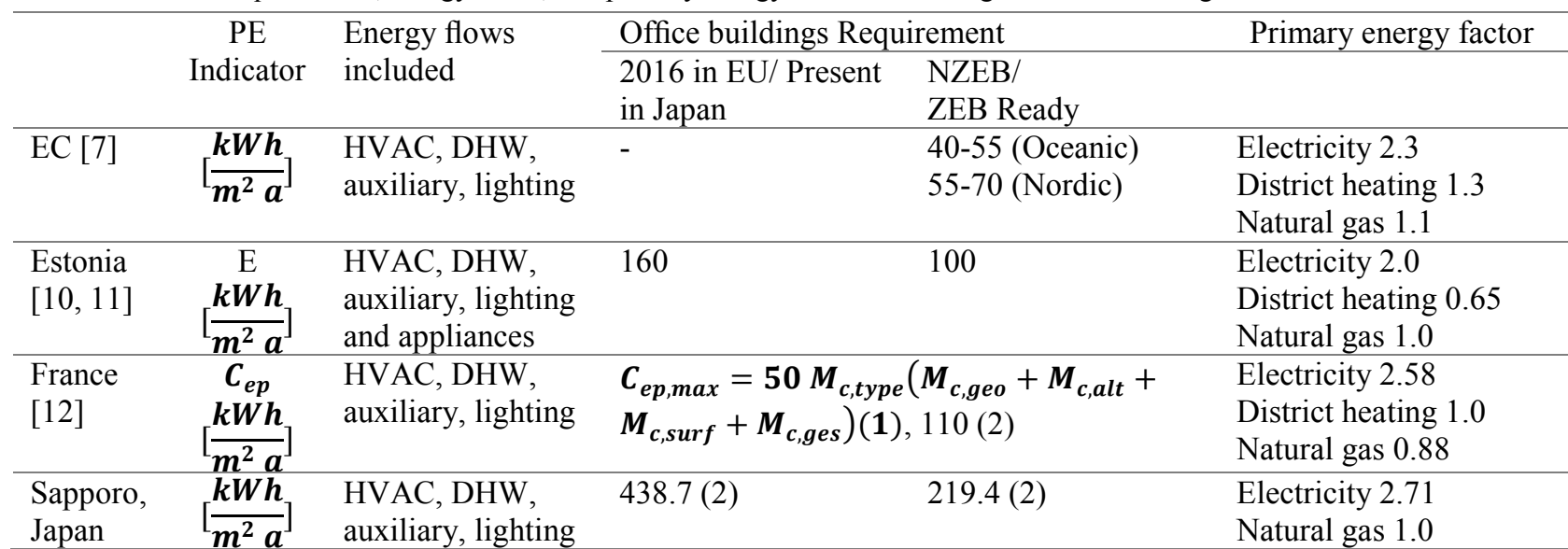

(1) Depending on building type and category coefficient $\left(M_{c, t y p e}\right)$, geographical location coefficient $\left(M_{c, \text { geo }}\right)$, altitude coefficient $\left(M_{c, \text { alt }}\right)$, commercial buildings floor surface coefficient $\left(M_{c, s u r f}\right)$, and greenhouse potential of the fuel used coefficient $\left(M_{c, g e s}\right)$, (2) The requirement value for the reference building used in this study.

The analysis was performed as follows:

1. The reference office building was simulated with Japanese WEBPRO programme with Japanese input data (Table 3);

2. The reference office building was simulated with IDA ICE simulation tool with Japanese input data (Table 3) with the aim to continue analyses with this tool;

3. Improved building and system parameters were determined in order to reduce the primary energy compared to the present requirement by $50 \%$ (Japanese ZEB Ready);

4. Japanese ZEB Ready building model (obtained in step 3) were moved from Japanese (Sapporo) climate to Estonian and French climates with considering an additional adjustment of insulation thickness and ' $U$ value'. These building models were simulated with national input data and climate files;

5. Adjusted building models, obtained from step 4, were simulated with EN16798-1 input data and compared with EC benchmark;

6. Additional building and system parameters were improved (if required) in order to comply with EC benchmarks for Oceanic and Nordic zones;

7. Obtained models in step 6 were moved from Estonian and French climates to the Japanese (Sapporo) climate with an additional adjustment of insulation thickness and ' $U$ value' of window. Both models were simulated with Japanese input data and climate file to show the effect of improvements in step 6 compared to Japanese ZEB Ready.

\subsection{Description of the reference office building}

Estonian cost optimal office building was considered as a reference building model, as shown in Figure 1 [6]. The building model had a net floor, envelope and window areas of $4451.8 \mathrm{~m}^{2}, 3993.9 \mathrm{~m}^{2}$ and $1326 \mathrm{~m}^{2}$, respectively. The model had a massive concrete frame and structure. The thermal transmittance of internal floors, external floors, internal walls and doors were $0.24,0.13,0.30,1.5$ $\mathrm{W} / \mathrm{m}^{2} \mathrm{~K}$, respectively and these values were the same for all cases [6]. The $U$ value of external walls, roof and windows were climate specified, as shown in Table 4. However, solar heat gain coefficient and solar transmittance was 0.22 and 0.148 for all cases [6]. Thermal bridges were found of $0.0336,0.0574,0.0519$, $0.0515,0.0254$, and $0.024 \mathrm{~W} / \mathrm{mK}$ for external wall to external wall, external wall to internal slab, external wall to roof, external wall to external slab, internal wall to roof, along window parameter, respectively that accounted total heat losses of $9 \%$ [6]. Also, at $50 \mathrm{~Pa}$ of pressure differences, the air leakage was $1.01 / \mathrm{h}$ for all cases. Furthermore, dynamic simulations were conducted by well-validated IDA ICE simulation tool [6].

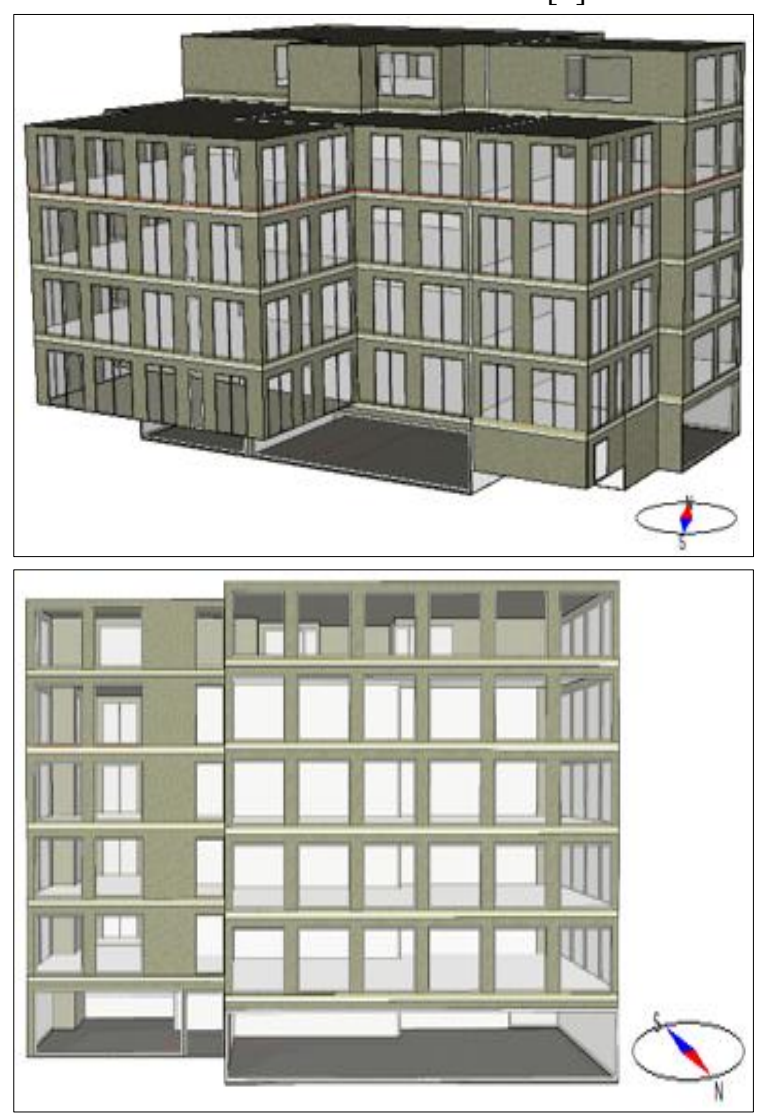

Fig. 1. Views of the simulated building model. 


\subsection{National input data and EC recommendation}

Input data has a significant impact on the overall primary energy calculation. The effect of input data has been more severe than the effect of the weather [8]. The input data used in different national regulations are listed in Table 3. The major difference between European and Japanese input data/indoor climate is the humidification that is in use in Japan, but not in the EU.

Table 3. Input data according to EN 16798-1:2018 and national building regulations.

\begin{tabular}{|c|c|c|c|c|}
\hline Input data & EU & Estonia & France & ${ }^{\mathrm{a} J a p a n ~(S a p p o r o)}$ \\
\hline Occupant, $\mathrm{m}^{2} /$ person & 17 & 17 & 10 & 10 \\
\hline Appliances, $\mathrm{W} / \mathrm{m}^{2}$ & 12 & 12 & 5.7 & 12 \\
\hline Lighting, $\mathrm{W} / \mathrm{m}^{2}$ & 6 & 6 & 8 & ${ }^{\mathrm{b}} 16.3 / 6$ \\
\hline $\begin{array}{l}\text { Air volume flow by re- } \\
\text { circulation, } \mathrm{m}^{3} / \mathrm{h} . \mathrm{m}^{2}\end{array}$ & N/A & N/A & N/A & ${ }^{\mathrm{c}} 17.1$ \\
\hline $\begin{array}{l}\text { Appliances \& lighting } \\
\text { operation hour }\end{array}$ & 7:00-18:00 & 7:00-18:00 & $8: 00-18: 00$ & $8: 00-21: 00$ \\
\hline Usage factor & 0.55 & 0.55 & 0.6 & 0.89 \\
\hline DHW, $1 / \mathrm{m}^{2} \mathrm{a}$ & 100 & 100 & 65 & 91.58 \\
\hline Fan operation hour & $6: 00-19: 00$ & $6: 00-19: 00$ & $6: 00-19: 00$ & $7: 00-21: 00$ \\
\hline Ventilation rate, $1 / \mathrm{m}^{2} \mathrm{~s}$ & 1.4 & 2.0 & 0.5 & 1.39 \\
\hline Heating set point, ${ }^{\circ} \mathrm{C}$ & 21 & 21 & 20 & 22 \\
\hline Cooling set point, ${ }^{\circ} \mathrm{C}$ & 25 & 25 & 26 & 26 \\
\hline Floor heating efficiency & 0.97 & 0.97 & 0.97 & 0.97 \\
\hline Generation efficiency, GB & 0.95 & - & 0.95 & - \\
\hline Generation efficiency, DH & 1.0 & 0.9 & - & - \\
\hline d ASHP's COP for heating & 2.74 & 2.74 & 2.74 & 2.74 \\
\hline${ }^{\mathrm{d}}$ ASHP's EER for cooling & 3.24 & 3.24 & 3.24 & 3.24 \\
\hline
\end{tabular}

${ }^{a}$ Relative humidity during heating season should not be less than $40 \%$ and not more than $50 \%$ during cooling season;

${ }^{\mathrm{b}}$ Lighting power for present and NZEB are 16.3 and $6.0 \mathrm{~W} / \mathrm{m}^{2}$, respectively;

${ }^{c}$ Re-circulation was used only with present regulation and was not applied to Japanese NZEB

'The values of air source heat pump (ASHP)'s coefficient of performance (COP) and energy efficiency ratio (EER) followed Japanese ASHP's values at rated condition. The same values were used in Estonian, French and EU cases to keep the comparison transparent.

To compare the national NZEB benchmark to EC benchmark, it is needed to account the same energy flows for all cases. For instance, Estonian office building required $19.0 \mathrm{kWh} / \mathrm{m}^{2}$.a of delivered energy for appliances, which gave primary energy of $38 \mathrm{kWh} / \mathrm{m}^{2}$.a (PEF for electricity 2.0, Table 2). After the deduction of appliance energy form the Estonian NZEB benchmark $\left(100 \mathrm{kWh} / \mathrm{m}^{2} . \mathrm{a}\right)$ the comparable value is $62 \mathrm{kWh} / \mathrm{m}^{2}$.a. The direct comparison of national NZEB requirements and EC recommendation of net primary energy are shown in Figure 2.

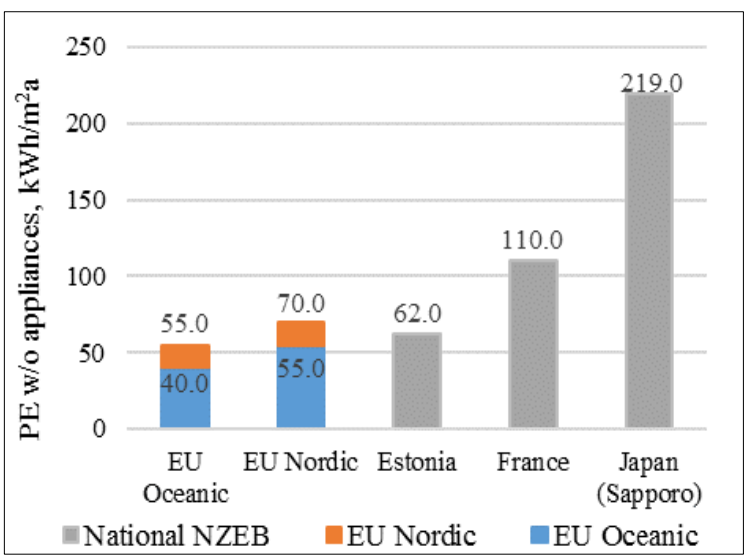

Fig. 2. Direct comparison of national NZEB requirements, Japanese ZEB Ready and EC recommendation of net primary energy (appliances not included).

\section{Results and analysis}

\subsection{Energy performance requirements of Japanese buildings according to the present regulation}

Energy performance of Japanese office buildings was estimated according to the WEB-Based program WEBPRO, which was produced by the Japanese Building Research Institute. Input data were applied for estimating of minimum obligation that is applicable for present building regulation. Thermal transmittance coefficients (U value) for external wall, roof and window glaze were $0.614,0.317$, and $2.64 \mathrm{~W} / \mathrm{m}^{2} \mathrm{~K}$, respectively. In WEBPRO programme, electric power need for ASHP is calculated from using performance curves corresponding to partial load ratio and outdoor air temperature. Thus, COP of ASHP is varied depend on load ratio and outdoor air temperature. However, simulation in this paper, COP of ASHP was fixed as rated COP for cooling and heating operation respectively. The WEBPRO programme estimated the energy performance of reference building (Figure 1) of $438.7 \mathrm{kWh} / \mathrm{m}^{2} \mathrm{a}$, as shown in Figure 3. The simulation was repeated with IDA-ICE energy simulation tool keeping the same building model and input data in resulting in $446 \mathrm{kWh} / \mathrm{m}^{2} \mathrm{a}$, so the difference of $1.6 \%$ primary energy (PE), as shown in Figure 3. 


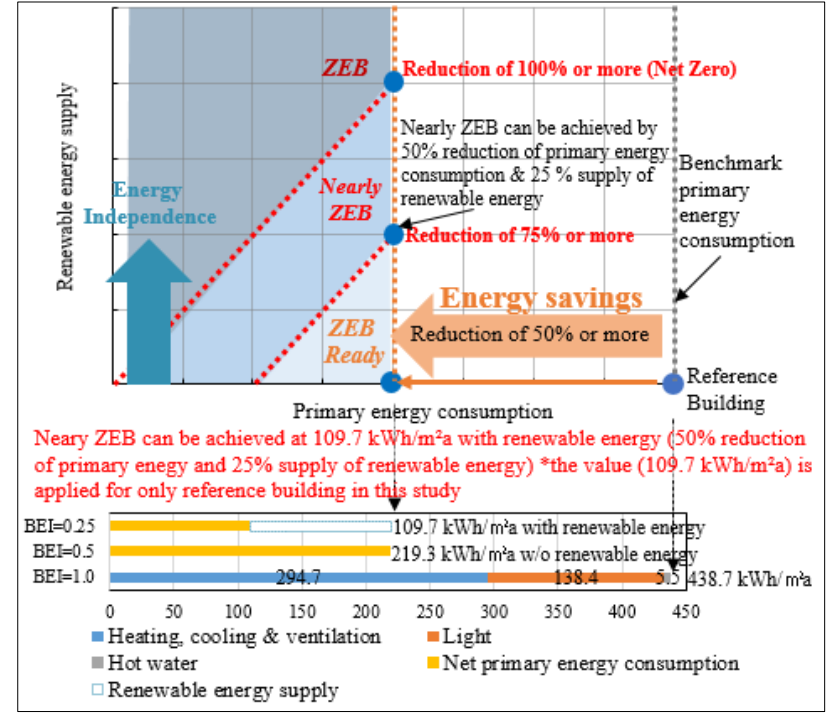

(a)

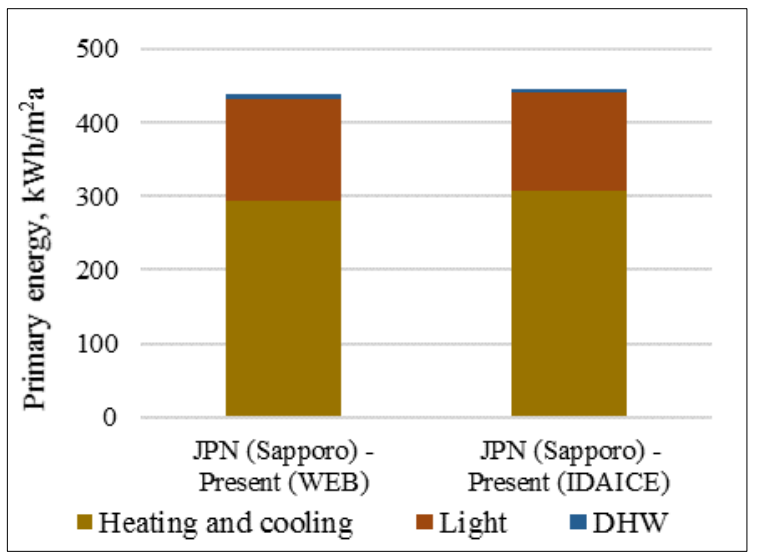

(b)

Fig. 3. a) Energy performance of reference building according to present regulation, b) Estimation of primary energy need by WEB based programme and IDA ICE simulation tool.

\subsection{Energy performance requirements of Japanese NZEB buildings}

Energy performance requirements in Japan are based on BEI indicator, which is the ratio of design and standard value representing so-called reference-building method. $\mathrm{BEI}=1.0$ is the minimum requirement and $\mathrm{BEI}=0.5$ is set for ZEB Ready with the aim to reduce primary energy by $50 \%$ compared to the present energy requirement. Primary energy includes energy uses for HVAC, domestic hot water and lighting. The standard value of primary energy is determined by multiplying the reference value by each floor area and summing them. The reference value for each energy use has been defined depending on the 8 climate regions, 8 building types, and 201 room types. The reference value for HVAC is estimated according to the heat load calculated based on the input data as shown in Table 3 and the system performance of prescribed HVAC system. Official tool, WEBPRO is used to simulate the standard value as well as the designed value for. There is no established practice for thermal transmittance of building envelope, window, the efficiency of heat recovery, installed lighting etc. yet. Thus, in this study, these properties of ZEB Ready (Table
3) were defined. Re-circulation was not used in order to save energy in Japanese ZEB Ready, but this was used in the Japanese present building model. In addition, the efficiency of heat recovery and specific fan power were improved to $80 \%$ and $1.56 \mathrm{~kW} / \mathrm{m}^{3} \mathrm{~s}$, respectively. The breakdown of energy use is shown in Figure 4. Energy use for lighting was reduced from 133 to $47 \mathrm{kWh} / \mathrm{m}^{2} \mathrm{a}$ by changing the installed power from 16.3 to $6.0 \mathrm{~W} / \mathrm{m}^{2}$. As a result, space heating reduced from 63 to $18 \mathrm{kWh} / \mathrm{m}^{2} \mathrm{a}$ after these improvements.

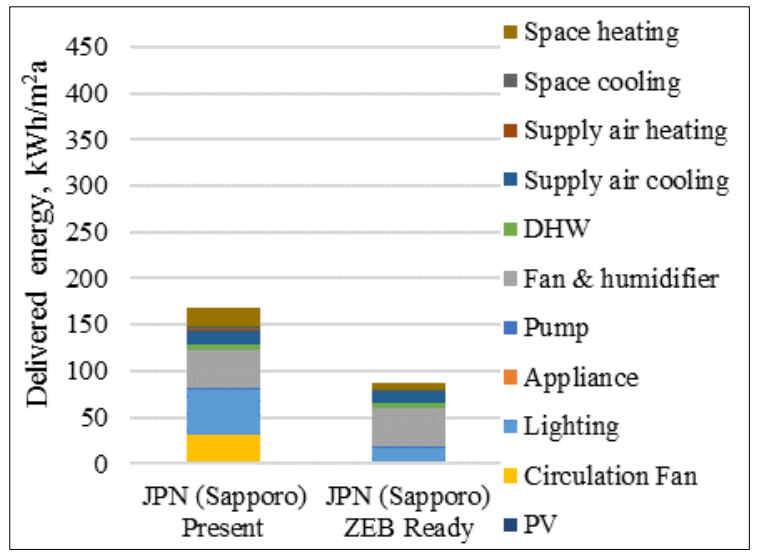

(a)

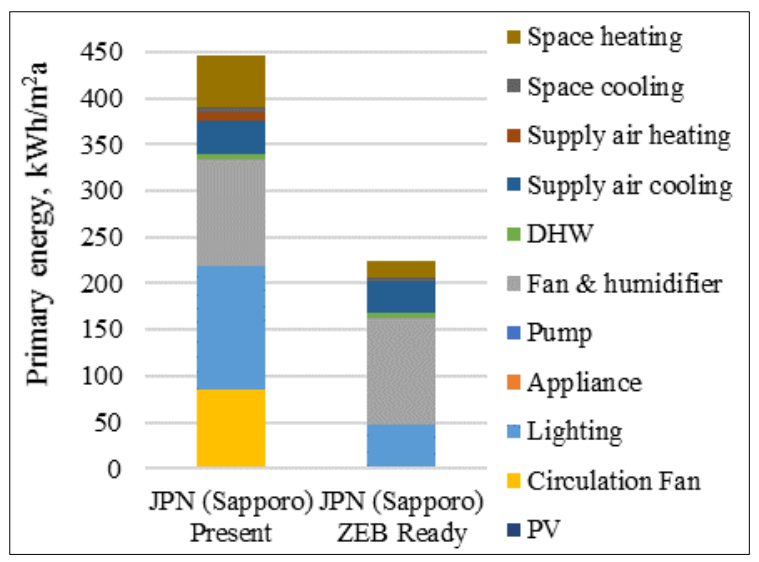

(b)

Fig. 4. Energy use according to present and ZEB Ready regulations in reference building a) Delivered energy, and b) Primary energy.

\subsection{Thickness adjustment of the external walls and window glaze}

The aim of this section is to show the energy performance of a building when it moves from one to another climate. The insulation thickness and U-value of glazing were estimated according to equation (4) as shown in Table 3. Japanese ZEB Ready building model with adjusted Uvalue and corresponding national climate files was used in order to find the building energy performance at different climates, as shown in Figure 5. According to the Japanese regulation, indoor relative humidity needs to be kept within the range, which required additional installation of humidifier (Table 3). Energy use of a humidifier is reported for Japanese ZEB Ready under the fan's energy segment. Long operation hours, high usages rate, schedule-control of lighting system have resulted in a significant contribution of lighting energy in Japan. 
Estonian regulation accounts additionally the appliance energy, which is not accounted in energy flows for Japanese and French NZEB regulation. The common energy source in Estonia and France, district heating (DH) and gas boiler (GB) were used, and the common ASHP in Japan was also used for Estonian and French buildings.

Table 4. Adjusted insulation thickness and U value.

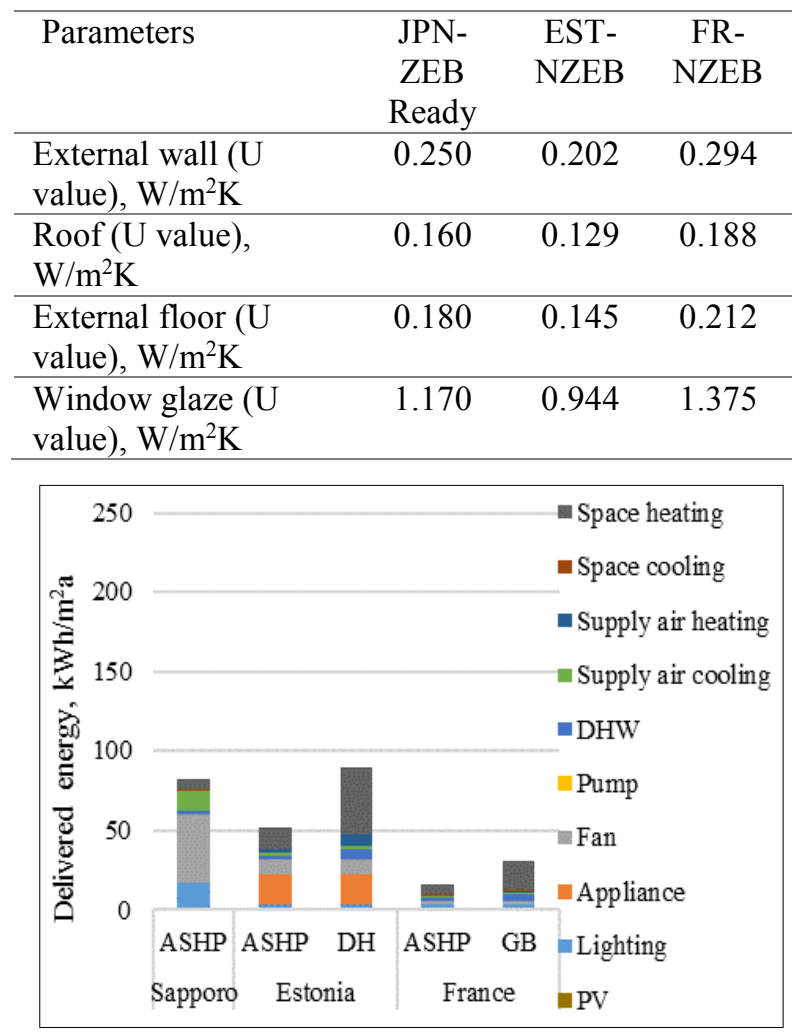

(a)

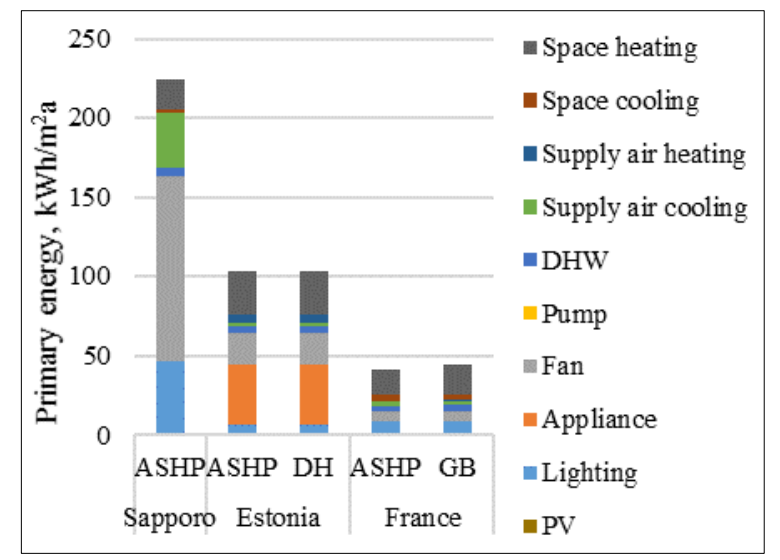

(b)

Fig. 5. Energy use of reference building in Japanese (Sapporo), Estonian and French climates a) Delivered energy, b) Primary energy.

Results show an additional improvement need of the building parameters in Estonian cases due to exceeding of national NZEB requirement of $100 \mathrm{kWh} / \mathrm{m}^{2} \mathrm{a}$ by 3.7 $\mathrm{kWh} / \mathrm{m}^{2} \mathrm{a}$ with ASHP and $3.3 \mathrm{kWh} / \mathrm{m}^{2} \mathrm{a}$ with DH system. However, French building resulted in 41.7 and 44.1 $\mathrm{kWh} / \mathrm{m}^{2}$ a with ASHP and GB system, respectively, which is far from the NZEB requirement of $110 \mathrm{kWh} / \mathrm{m}^{2} \mathrm{a}$ showing more freedom to change building and system parameters for achieving closer compliance with NZEB benchmark.

The same building models were simulated with EC input values and by keeping Estonian and French climate files in order to see either the energy performance of buildings compliance with EC benchmark (Table 1) as shown in Figure 6.

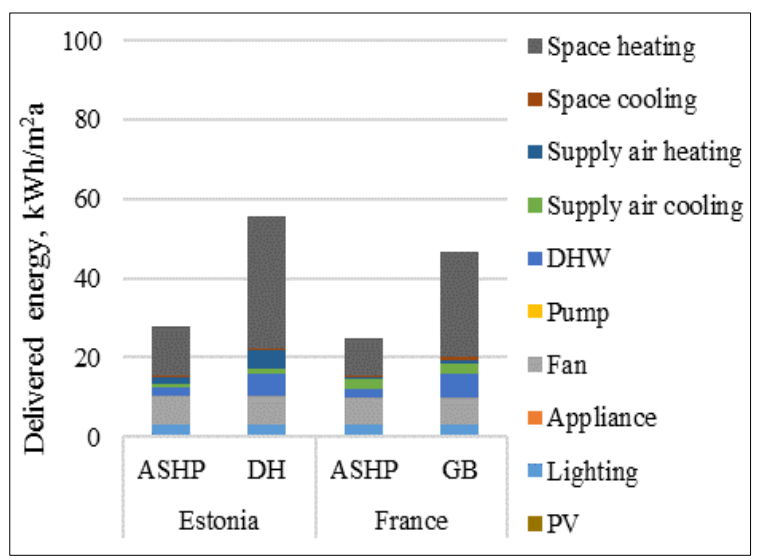

(a)

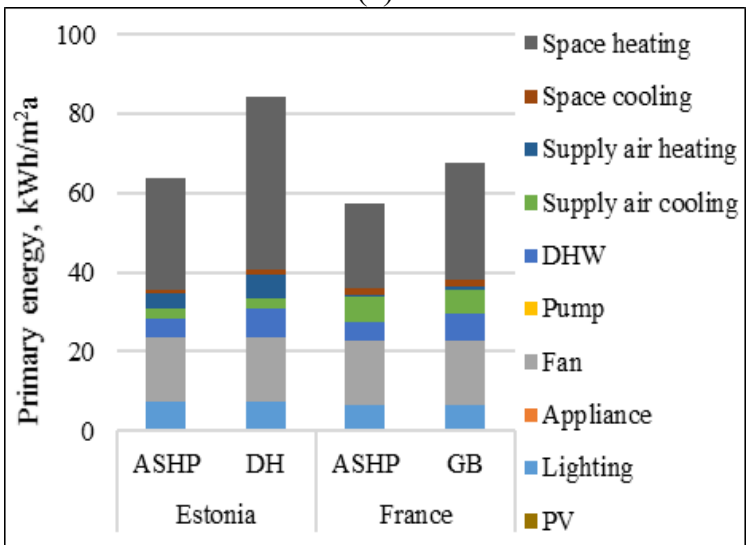

(b)

Fig. 6. Energy use of reference building in Estonian and French climates a) Delivered energy, and b) Primary energy.

The primary energy of Estonian and French buildings with ASHP heat source were 63.9 and $57.4 \mathrm{kWh} / \mathrm{m}^{2} \mathrm{a}$, respectively. Additional improvement was only required for French building, which needed small amount of PV panels only. In the case of DH and GB heat sources, Estonian and French primary energy were 84.2 and 67.5 $\mathrm{kWh} / \mathrm{m}^{2} \mathrm{a}$, respectively, showing that further improvement of building and system parameters is required in order to achieve the compliance with EC benchmark. The following improvements were considered, which energy performances are shown in Figure 7.

- Building in French climate (ASHP system) - added PV panel of $0.9 \mathrm{~kW}$,

- Building in Estonian climate (DH system) - external wall $\left(0.17 \mathrm{~W} / \mathrm{m}^{2} \mathrm{~K}\right)$, roof $\left(0.11 \mathrm{~W} / \mathrm{m}^{2} \mathrm{~K}\right)$, window $(0.8$ $\left.\mathrm{W} / \mathrm{m}^{2} \mathrm{~K}\right)$, added PV panel of $3.93 \mathrm{~kW}$,

- Building in French climate (GB system) - external wall $\left(0.25 \mathrm{~W} / \mathrm{m}^{2} \mathrm{~K}\right)$, roof $\left(0.16 \mathrm{~W} / \mathrm{m}^{2} \mathrm{~K}\right)$, window $(1.0$ $\left.\mathrm{W} / \mathrm{m}^{2} \mathrm{~K}\right)$, added PV panel of $2.56 \mathrm{~kW}$. 


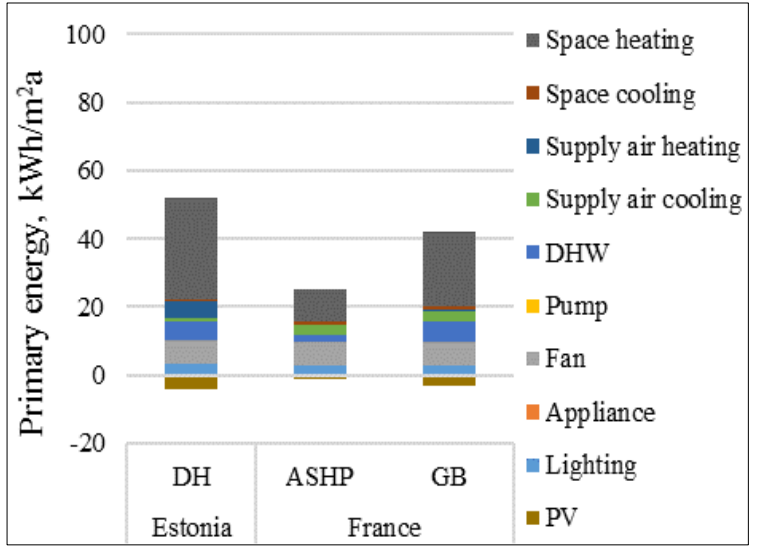

(a)

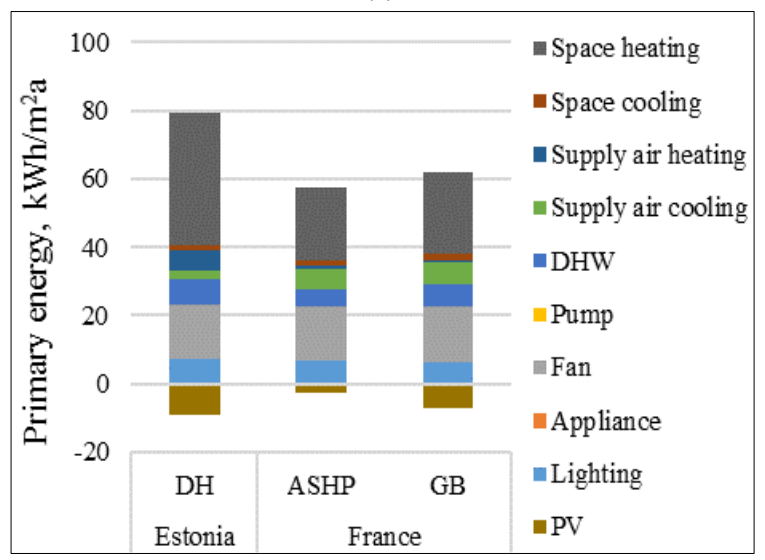

(b)

Fig. 7. Energy use of reference building after improving the building and system parameters a) Delivered energy, b) Primary energy.

\subsection{Japanese ZEB Ready corresponding to EC benchmark}

The building model with improved parameters (meeting EC benchmark, Section 3.3) was moved to the Japanese climate (Sapporo) to get the energy performance that is equivalent to the EC benchmark. Thermal insulation was adjusted for a building model that moved from Estonia to Japan and France to Japan as shown in Table 5.

Table 5. Adjusted insulation thickness and $U$ value.

\begin{tabular}{cccc}
\hline External & Roof & External & Window \\
wall $(\mathrm{U}$ & $(\mathrm{U}$ & floor $(\mathrm{U}$ & glaze $(\mathrm{U}$ \\
value), & value), & value), & value), \\
$\mathrm{W} / \mathrm{m}^{2} \mathrm{~K}$ & $\mathrm{~W} / \mathrm{m}^{2} \mathrm{~K}$ & $\mathrm{~W} / \mathrm{m}^{2} \mathrm{~K}$ & $\mathrm{~W} / \mathrm{m}^{2} \mathrm{~K}$ \\
\hline
\end{tabular}

Building moved from Estonian to Japanese (Sapporo) climate

$\begin{array}{lllll}\text { EST } & 0.170 & 0.110 & 0.145 & 0.800 \\ \text { JPN } & 0.199 & 0.129 & 0.170 & 0.937\end{array}$

Building moved from French to Japanese (Sapporo) climate

\begin{tabular}{ccccc}
\hline FR & 0.250 & 0.160 & 0.180 & 1.000 \\
\hline JPN & 0.174 & 0.111 & 0.125 & 0.695 \\
\hline
\end{tabular}

The breakdown of energy use in the Japanese (Sapporo) climate is shown in Figure 8. The primary energy need was $182.8 \mathrm{kWh} / \mathrm{m}^{2} \mathrm{a}$ (model moved from Estonia to Japan), and the variation of primary energy was found of $40.2 \mathrm{kWh} / \mathrm{m}^{2}$ a compared to initial Japanese benchmark $\left(223 \mathrm{kWh} / \mathrm{m}^{2} \mathrm{a}\right)$. In contrast, if the model moved from French to the Japanese (Sapporo) climate then the primary energy need was $184.3 \mathrm{kWh} / \mathrm{m}^{2} \mathrm{a}$ and the variation of primary energy was found of $38.7 \mathrm{kWh} / \mathrm{m}^{2} \mathrm{a}$ compared to initial Japanese benchmark. EC benchmark for the Nordic zone (Estonia) seems therefore equally strict compared to Oceanic zone (France). Estonian national NZEB requirement was more ambitious compared to France national NZEB benchmark as it fulfilled the EC benchmark.

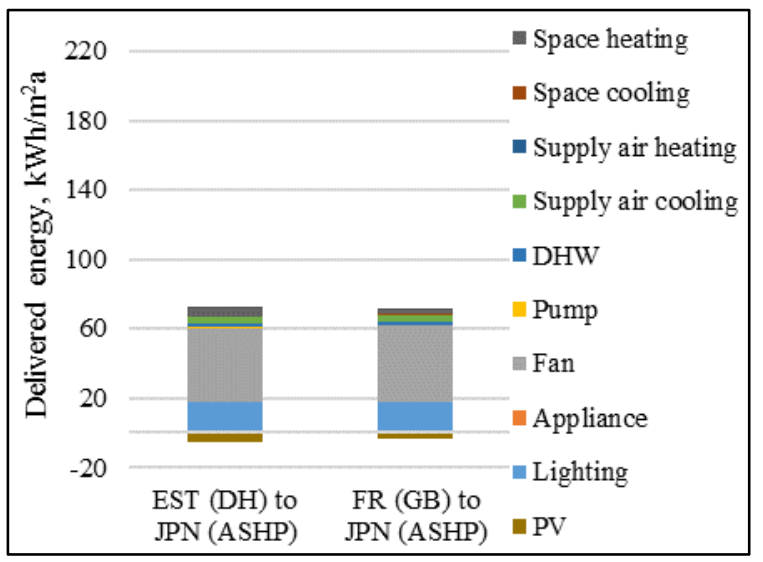

(a)

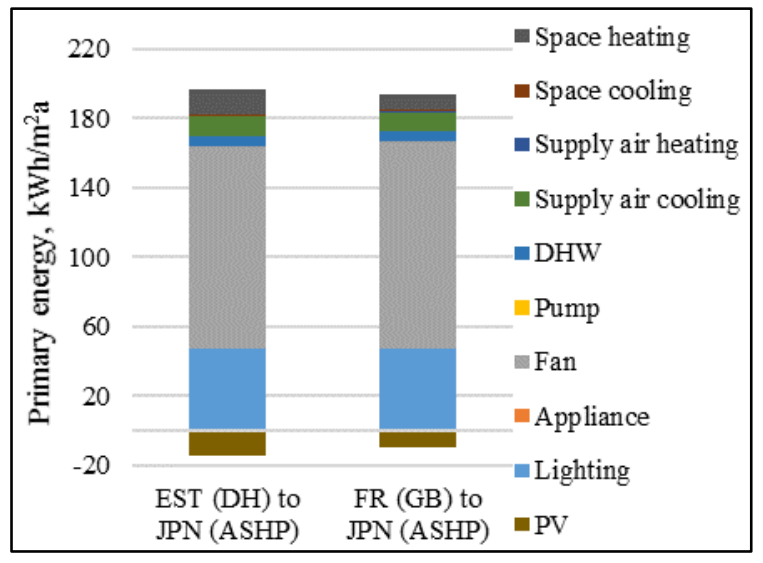

(b)

Fig. 8. Energy use in Japanese Sapporo climate corresponded to EC benchmark a) Delivered energy, and b) Primary energy.

\section{Conclusion}

This study developed a building simulation method, where HDD was determined from the thermal conductance of the building and simulated energy need for heating corresponding to the reference climate. The results generated economical insulation thickness for another climate. This method overcame the complexity of selecting a base temperature needed in HDD calculation, which was addressed in previous studies [6,9]. Compared to the base temperature, thermal conductance is a straightforward building parameter not depending on the dynamics of climatic variables.

This building simulation method generated HDD for any climate compared to the reference climate, which further allowed to get the optimum insulation thickness for the corresponding climate. This optimum insulation thickness allows one to move a building from one to another climate with corresponding changes of energy needs. Japanese ZEB Ready reference building configuration of $223 \mathrm{kWh} / \mathrm{m}^{2} \mathrm{a}$ primary energy was 
moved from Japanese climate (Sapporo) to Estonian and French climates. The adjusted building model with Estonian input value resulted of $3.3 \mathrm{kWh} / \mathrm{m}^{2} \mathrm{a}$ higher primary energy than the national NZEB requirement (100 $\mathrm{kWh} / \mathrm{m}^{2} \mathrm{a}$ ), whereas French building required 44.1 $\mathrm{kWh} / \mathrm{m}^{2} \mathrm{a}$ (NZEB requirement $110 \mathrm{kWh} / \mathrm{m}^{2} \mathrm{a}$ ), showing a freedom to change the building and system parameters in the case of less strict national requirement. These building models with EC input values and ASHP resulted to 63.9 and $57.4 \mathrm{kWh} / \mathrm{m}^{2} \mathrm{a}$ in Estonian (Nordic) and French (Oceanic) climates that is close to EC NZEB benchmark of 70 and $55 \mathrm{kWh} / \mathrm{m}^{2}$ a for Nordic and Oceanic, showing that Japanese ZEB Ready building configuration with ASHP complies well with EC NZEB benchmark. However, with commonly used district heat and gasboiler heat sources, the result was 84.2 and $67.5 \mathrm{kWh} / \mathrm{m}^{2} \mathrm{a}$ in Estonian (Nordic) and French (Oceanic) climates respectively. These values are higher than EC NZEB benchmarks showing that Japanese ZEB Ready building configuration needed to be improved with these heat sources in order to comply with EC NZEB benchmarks.

Improved Japanese ZEB Ready building configuration which was EC complaint with district heating and gas boiler were moved to Japanese (Sapporo) climate with adjusted insulation thickness and ' $U$ value' of windows in order to see how much Japanese primary energy will change compared to original ZEB Ready. The primary energy of Estonian building model with adjusted insulation and Japanese input value was $182.8 \mathrm{kWh} / \mathrm{m}^{2} \mathrm{a}$, which is 40.2 unit less than the initial Japanese ZEB Ready $223 \mathrm{kWh} / \mathrm{m}^{2} \mathrm{a}$. Improved French building model with adjusted insulation and Japanese input value resulted in $184.3 \mathrm{kWh} / \mathrm{m}^{2} \mathrm{a}$, i.e. $38.7 \mathrm{kWh} / \mathrm{m}^{2}$ a less in Japanese (Sapporo) climate compared to original Japanese ZEB Ready. Thus, the building configuration of Japanese ZEB Ready needed some improvement to meet EC benchmarks with district heat and gas boiler. Consequently, Estonian NZEB requirement fulfilled EC benchmark, and French NZEB requirement was clearly less ambitious than EC benchmark.

\section{Acknowledgement}

This research was supported by REHVA Technology and Research Committee, Special Committee for Joint Study on NZEB between SHASE and REHVA, The Society of Heating, Air-Conditioning and Sanitary Engineering of Japan (SHASE), and by the Estonian Centre of Excellence in Zero Energy and Resource Efficient Smart Buildings and Districts, ZEBE, grant 2014-2020.4.01.15-0016 funded by the European Regional Development Fund.

\section{Reference}

[1] C. Giannakopoulos, P. Hadjinicolaou, C. Zerefos and G. Demosthenous, "Changing energy requirements in the Mediterranean under changing cimatic conditions " Energies, vol. 2, no. 4, pp. 805-815 (2009).

[2] J.C. Lam, H.L. Tang and D.H.W. Li, "Seasonal variations in residential and commercial sector electricity consumption in Hong Kong," Energy, vol. 33, no. 3, pp. 513-523 (2008).

[3] J. Karlsson, A. Roos and B. Karlsson, "Building and climate influence on the balance temperature of buildings," Build. Environ., vol. 38, no. 1, pp. 75-81 (2003).

[4] Z. Y1lmaz, "Evaluation of energy efficient design strategies for different climatic zones: Comparison of thermal performance of buildings in temperate-humid and hot-dry climate," Energy Build., vol. 39, no. 3, pp. 306316 (2007).

[5] M. Hekkenberg, H.C. Moll and A.J.M.S. Uiterkamp, "Dynamic temperature dependence patterns in future energy demand models in the context of climate change," Energy, vol. 34, no. 11, pp. 1797-1806 (2009).

[6] K. Ahmed, M. Carlier, C. Feldmann and J. Kurnitski, "A new method for contrasting energy performance and near-zero energy building requirements in different climates and countries," Energies, vol. 11, no. 6 (2018).

[7] "Commission Recommendation (EU) 2016/1318 of 29 July 2016 on guidelines for the promotion of nearly zeroenergy buildings and best practices to ensure that, by 2020 , all new buildings are nearly zero-energy buildings." (2016).

[8] J. Kurnitski, K. Ahmed, T. Hasu, T. Kalamees, N. Lolli, A. Lien, T. Johan and J. Jan. "NZEB energy performance requirements in four countries vs. European commission recommendations," Proceedings of the REHVA Annual Meeting Conference, Low Carbon Technology in HVAC, Brussels, Belgium (2018).

[9] J. Kurnitski, V. Grönlund and E. Reinikainen. "Comparison of energy performance requirements in selected countries," CLIMA 2013. In: 11th REHVA World Congress and the 8th international conference on indoor air quality, ventilation and energy conservation in buildings, Prague, Czech Republic, June 16-19 (2013).

[10] "Estonian government. Methodology for calculating the energy performance of buildings," (2012).

[11] "Estonian government. Minimum requirements for energy performance," (2014).

[12] "Centre Scientifique et Technique du Batiment (CSTB). Methode de Calcul Th-BCE 2012; Centre Scientifique et Technique du Batiment: Saint-Martind'Hères, France," (2012). 